\title{
Does Indonesian COVID-19 Emergency Law Secure Rule of Law and Human Rights? ${ }^{1}$
}

\author{
Herlambang P. Wiratraman \\ Center of Human Rights Law Studies (HRLS), Faculty of Law Universitas Airlangga \\ Email: herlambang@fh.unair.ac.id
}

\begin{abstract}
President Joko Widodo announced a public health emergency at the end of March 2020. This policy demonstrates denial, too late and limited in responding to the spread of Covid19. On the other hand, the state security approach during the pandemic has pressured civil liberties, especially criticisms against government policies. This phenomenon is not a new development in Indonesia whereby attacks on freedom of expression and academic freedom are common. This article analyses how the COVID-19 health emergency situation is handled by the government from the perspective of human rights law standards and the rule of law. This article argues the Indonesian COVID-19 emergency law violates many guarantees of legal protection under the rule of law standard. It is apparent how the issue of human rights has not yet become an effective strategy or approach in this non-natural disaster emergency situation.
\end{abstract}

Keywords: Covid-19, Rule of Law, Human Rights, Freedom of Expression, Emergency Powers

\section{COVID-19 IN INDONESIA: AN INTRODUCTION}

The Indonesian government is in self-denial. The government has continually denied the coronavirus issue since January 2020. It has lost 2.5 months to respond effectively in order to prevent coronavirus from spreading. The denial position is linked with 'anti-scientism' which rejects the argument that the virus had been affecting the community, although there have been no confirmed Covid-19 cases. This denial due

1 Paper is based on the presentation at the 'Law on the State of Emergency' Conference, 16 and 17 June 2020, jointly organized by: School of Law, Vietnam National University, Hanoi and Asian Law Centre, Melbourne Law School, The University of Melbourne in cooperation with the Institute of Legislative Studies under the Standing Committee, the National Assembly of Vietnam. 
to Indonesia's inability to detect coronavirus (referred to as 'false negative' result) in early infected situations. ${ }^{2}$

At that time there was widespread disinformation across the community although this period was the best time to prevent the coronavirus from entering Indonesia. An Epidemiologist from the University of Indonesia, Pandu Riono stated, "...since January we have been expecting [suspected corona cases in Indonesia] and are also upset, how come the [case] reports continue to be negative. Denial position of the government was also unusually high.” This concern is reasonable and relevant, after the epidemiologist from Eijkman Oxford Clinical Research Unit, Iqbal Elyazar, stated thus far Indonesia does not have a valid epidemic curve. The government did not close tourist destinations, instead facilitated wider access for tourists with numerous incentive policies. ${ }^{3}$

Scientists feel they not been included by government when making decisions, hence any statements advising Indonesia is safe from the coronavirus, have no scientific basis. ${ }^{4}$ According to Professor Jeremy Rossman, President and founder of Research-Aid Networks, the problem of the coronavirus pandemic becomes more complex when there is not enough scientific data and facts. ${ }^{5}$

In early March, Achmad Yurianto, the Director-General for Disease Control at Indonesia's Ministry of Health, told Science Magazine, he was impervious to scientific opinion relating to the pandemic as "they are not important if their information only creates panic." The Minister of Health Terawan Agus Putranto suggested that prayer could help keep COVID-19 out of the country. ${ }^{6}$

In an anti-science power structure, science becomes a political accessory. Many intellectuals engaged in 'acrobatic' politics in this bureaucratic environment, by defending the Government despite its denial of science. This highlighted by Arif in his report on Science and Power Relations. ${ }^{7}$

2 BioTechniques, "Dangers of False Negative COVID-19 PCR Tests", (29 May 2020), online: <https://www.biotechniques.com/coronavirus-news/false-negatives-how-accurate-are-pcr-testsfor-covid-19/>; Kumparan, "Peneliti UI soal Corona Masuk RI SejakJanuari: Pemerintah Sudah Tahu”, (20 April 2020), online: Kumparan <https://kumparan.com/kumparansains/ peneliti-uisoal-corona-masuk-ri-sejak-januari-pemerintah-sudah-tahu-1tG7sajI5ob>.

3 Ahmad Arif, "Iqbal Elyazar: Jadikan Epidemiologi Memandu Indonesia”, (20 May 2020), online: Kompas <https://kompas.id/baca/humaniora/ilmu-pengetahuan-teknologi/2020/05/20/ iqbal-elyazar-jadikan-epidemiologi-memandu-indonesia/>.

4 Tempo, "Ilmuwan Indonesia Merasa Tidak Dilibatkan Dalam Menangani Virus Corona (ABC Australia)", TempoCo (18 May 2020), online: <https://www.tempo.co/abc/ 5597/ilmuwanindonesia-merasa-tidak-dilibatkan-dalam-menangani-virus-corona>.

$5 \quad$ Ibid.

6 Rochmyaningsih Dyna, “Open the doors for us.' Indonesian scientists say government snubs offers to help fight coronavirus" Science Magazine (18 April 2020), online: <https://www. sciencemag.org/news/2020/04/open-doors-us-indonesian-scientists-say-government-snubs-offers -help-fight-coronavirus>.

7 Ahmad Arif, "Ilmuwan dan Kekuasaan”, (13 May 2020), online: Kompas <https://kompas. id/baca/humaniora/ilmu-pengetahuan-teknologi/2020/05/13/ilmuwan-dan-kekuasaan/>. 
On the other hand, without considering scientific proposals, President Joko Widodo acknowledged that the government hid information related to the handling of the coronavirus (COVID-19). He stated, not all information can be conveyed to the public to avoid panic. Jokowi stated,

"I say that the handling of the Covid-19 pandemic continues to be our concern. Indeed, there is something that we convey and some that we do not convey. Because we do not want to cause unrest and panic in the community."

Under Indonesian law, concealing information relating to COVID-19 handling policies is contrary to the 1945 Constitution of the Republic Indonesia ${ }^{9}$ and Law Number 14/2008 concerning Public Information Openness. ${ }^{10}$

The Government through Presidential Decree (Keppres) 7/2020, created a Task Force for the Acceleration Handling of Coronavirus Disease 2019 (COVID-19), March 13, 2020. The Task Force was formed due to the spread of COVID-19 across the globe, causing fatalities and material losses, which has implications for social, economic, and community welfare. In addition, the World Health Organization (WHO) declared COVID-19 a pandemic on the 11th March 2020. ${ }^{11}$ With the Presidential Decree, the government could anticipate its impact, including handling the situation quickly, appropriately and in a focused, integrated and synergic manner whilst facilitating a response between ministries/agencies and local governments.

The Presidential Decree was revised again, with the consideration of adding ministries or institutions to the Task Force for the Acceleration Handling of Corona Virus Disease 2019. In the new structure, there were 32 implementers, from the previous 12 institutions. ${ }^{12}$

The two presidential decrees were not statements of emergency, rather they were communications as to the formation of a Committee on handling COVID-19. Since then social distancing policies have been instigated that clearly restrict the rights of the population, yet no emergency status has been announced by the government. This clearly contradicts the principle of derogation which should have been stated earlier before the carrying out of social distancing policies.

8 Kompas, "Jokowi Akui Pemerintah Rahasiakan Sejumlah Informasi soal Corona”, Kompas (13 March 2020), online: <https://nasional.kompas.com/read/2020/03/ 13/16163481/jokowi-akuipemerintah-rahasiakan-sejumlah-informasi-soal-corona>.

9 Article $28 \mathrm{~F}$ of the Constitution: Every person shall have the right to communicate and to obtain information for the purpose of the development of his/her self and social environment, and shall have the right to seek, obtain, possess, store, process and convey information by employing all available types of channels.

10 The Law has been enacted on 30 April 2008.

11 Time, "World Health Organization Declares COVID-19 a 'Pandemic.' Here's What That Means” Time (11 March 2020), online: <https://time.com/5791661/who-coronavirus-pandemicdeclaration/>.

12 Presidential Decree 12/2020 on the change of Task Force for the Acceleration Handling of Corona Virus Disease 2109 (Covid-19), 20 March 2020 
In addition to constitutional mistakes in the application of emergency law, the government's political communication has been a blunder. The Institute for Research, Education, Economic and Social Information (LP3ES) has released research on President Joko Widodo's political communication during the COVID19 pandemic. They found within a 100 days since the coronavirus outbreak in Indonesia, (January 1 to April 5, 2020), 37 blunders or errors in communication, especially government statements related to the coronavirus. ${ }^{13}$ More seriously Indonesia's social-political system has been characterised as a democracy in decline or even worse, a return of authoritarianism. ${ }^{14}$

Amid the ever expanding COVID-19 distribution curve and the growing number of victims, the government announced a 'New Normal' policy. ${ }^{15}$ As of the 4th May 2020, Indonesia had 28,818 confirmed COVID-19 cases, including 1721 deaths. ${ }^{16}$ The 'New Normal' policy contradicts hospital conditions, whilst the COVID-19 Task Force Team has recorded 55 medical personnel have lost their lives during the COVID-19 pandemic. This consisted of doctors and nurses. ${ }^{17}$ On the other hand, a number of cities in Indonesia have not been able to implement the 'New Normal' policy. Moreover, the Corona PCR test ratio in Indonesia is the third lowest in Southeast Asia. ${ }^{18}$

Based on Worldometers data (6 May 2020), the total number of PCR tests in Indonesia reached 128,383. Indonesia ranks 6th out of 11 countries in Southeast Asia with Vietnam boasting the most PCR tests. The number is twice that of Indonesia at 261,004. If calculating per 1 million of the population, Indonesia is only able to test 469 people out of 1 million whilst Vietnam is able to test 2,681 people out of 1 million. On paper, the higher the number of tests, accumulates in more positive data being produced.

This provides a picture of the problem of handling COVID-19 in Indonesia, a problem that has not been overcome. That is why, it is necessary to see in terms of law and human rights, how the actual status of emergency law is used in order to make effective handling of Covid-19 in Indonesia.

13 Kompas, "LP3ES Catat Ada 37 Pernyataan Blunder Pemerintah soal Covid-19”, Kompas (6 April 2020), online: <https://nasional.kompas.com/read/2020/04/ 06/17522121/lp3es-catat-ada37-pernyataan-blunder-pemerintah-soal-covid-19>.

14 Thomas P Power, "Jokowi's Authoritarian Turn and Indonesia's Democratic Decline" (2018) 54:3 Bulletin of Indonesian Economic Studies 307-338.

15 Tempo, "Pernyataan Lengkap Jokowi Soal New Normal Damai dengan Covid-19", Tempo (16 May 2020), online: <https://nasional.tempo.co/read/1342885/pernyataan-lengkap-jokowi-soalnew-normal-damai-dengan-covid-19>.

16 Tirto, "Gugus Tugas COVID-19: 55 Tenaga Medis Meninggal Saat Pandemi Corona”, (6 May 2020), online: Tirto <https://tirto.id/flvF>.

17 Ibid.

18 Kumparan, "Rasio Tes PCR Corona di Indonesia Terendah Ketiga di Asia Tenggara”, (7May 2020), online: <https://kumparan.com/kumparannews/rasio-tes-pcr-corona-di-indonesia-terend ah-ketiga-di-asia-tenggara-1tMesGDnTUh>. 


\section{COVID-19 EMERGENCY LAW}

"The President states a state of emergency.

The terms and conditions of the danger situation are set out in the Law."

Article 12 of the Constitution of 1945

There are several ad definitions of emergency power. Emergency powers are special prerogatives that a government or a President can resort to in extraordinary situations such as war, insurgency, terrorist attacks or other severe threats to the State, environmental calamities, serious industrial accidents, pandemics or similar situations that threaten lives. ${ }^{19}$ It is commonly agreed these powers should only be used in such extraordinary circumstances, and even then only to the extent that the situation requires. ${ }^{20}$

Countries that uphold democratic and rule-of-law values face particular challenges in handling public emergencies, because the legally guaranteed rights associated with a democratic constitutional order can, in emergency situations, impede effective action. ${ }^{21}$ Emergency powers generally allow government powers to promptly respond to public emergencies in order to restore order and national security by suspending the ordinary legal system.22

States of emergency are built on the somewhat artificial dichotomy of norm and exception, which endorses a bifurcated approach to balancing the interests of societal goals and individual rights. "State of emergency" is therefore a label that may provide instant legitimacy to the greater limitation of human rights by government. ${ }^{23}$ Therefore, the conceptual rationale for states of emergency is relatively clear and is rooted in the nature of the exceptional. ${ }^{24}$ In general, a State of Emergency (keadaan darurat) can be interpreted as a statement by the authorities to delay a normal function of a number of powers held by the executive, legislative and judiciary, including also changing the normal life of citizens and government institutions, in the context of emergency response.

One of the key issues here is that emergency powers enable the partial or complete suspension of a state's normal legal system ${ }^{25}$ and the expansion of

19 Anna Khakee, Securing democracy : a comparative analysis of emergency powers in Europe, policy paper no 30 ed (Geneva Centre for the Democratic Control of Armed Forces (DCAF), 2009).

20 Ibid.

21 Albert H Y Chen, "Emergency powers, constitutionalism and legal transplants: the East Asian experience" in Arun K Thiruvengadam \& Victor V Ramraj, eds, Emergency Powers in Asia: Exploring the Limits of Legality (Cambridge University Press, 2009) 57.

22 Subrata Roy Chowdhury, Rule of Law in a State of Emergency: The Paris Minimum Standards of Human Rights Norms in a State of Emergency (London: Printer Publisher, 1989).

23 Scott Sheeran, "Reconceptualizing States of Emergency under International Human Rights Law: Theory, Legal Doctrine, and Politics” (2013) 34:3 Michigan Journal of International Law (Legal Doctrine, and Politics) 491.

$24 \quad$ Ibid at 499.

25 Giorgio Agamben, State of Exception, translated by Kevin Attell (Chicago: University of Chicago Press, 2005). 
government power with limiting individual liberties for a certain period. ${ }^{26}$ Another perspective says that emergency situation is also known as a state of danger. In France for instance, uses the term 'état de siège' to refer to a state of danger and the term 'emergency powers' or 'pouvoirs exceptionnels' to refer to emergency powers in a state of danger. ${ }^{27}$ The Philippines uses the terms 'national emergency' and 'state of war' to refer to a state of danger. Brazil uses the term 'state of siege' to refer to a state of danger. ${ }^{28}$ Whereas, the United States uses the term 'national emergency' for a state of emergency as defined in The National Emergency Act $1976 .{ }^{29}$ Indonesia uses two terms: the term 'keadaan darurat' to refer to a state of emergency, and the term 'keadaan bahaya' to refer to a state of danger. A state of emergency is based on the 1945 Constitution and Law 23/1959, while a state of danger refers to the Law 24/2007.

The authority could claim a state of emergency, but this cannot be relinquished from its obligation to provide human rights protection to its citizens. As stipulated by the Article 28J section 2, constitutionally, restriction could be carried by the state in order to 'morality, religious values, security and public order in a democratic society'. ${ }^{30}$

This is a consequence of the submission of the sovereignty of the people to the rulers as well as the obedience to all kinds of legal devices created by the rulers, as part of fundamental principles of the rule of law. As stated in Article 1 paragraph (2) of the Constitution of 1945 which states, "Sovereignty is in the hands of the people and implemented in accordance with the Fundamental Law". In addition to affirming the principle of sovereignty of the people, the Constitution of 1945 also emphasised a number of national goals to be achieved, one of which was to protect Indonesian nationality and blood, including protection of a constitutional set of citizens' rights, as enshrined in the 1945 Constitution.

In order to uphold the principles of sovereignty and to achieve national goals as defined by the Constitution of 1945, a President is elected through a general election process, in which the President has the role of exercising the authority of government, as stated in Article 4 paragraph (1) of the 1945 Constitution, President of the Republic of Indonesia holds the power of Government under the Constitution.

As emphasized of the exercise of sovereignty principle, in the event of a threat to national security and territorial integrity / sovereignty, the President has authority

26 Eric Barendt, An Introduction to Constitutional Law, Clarendon Law Series (Oxford: Oxford University Press, 1998).

27 Filip Bozinovic, "Finding the Limits of France's State of Emergency" (2017) 2017:4 ClaremontUC Undergraduate Research Conference on the European Union 13-31.

28 Vide: Title V Section II Brazil Constitution, Constitution of the Federative Republic of Brazil: Constitutional text of October 5, 1988, with the alterations introduced by Constitutional amendments no. 1/1992 through 64/2010 and by Revision Constitutional Amendments no. 1/1994 through 6/1994, p. 104.

29 Nan D Hunter, The Law of Emergencies: Public Health and Disaster Management (Burlington: Butterworth-Heinemann, 2009).

30 "In exercising his/her rights and freedoms, every person shall have the duty to accept the restrictions established by law for the sole purposes of guaranteeing the recognition and respect of the rights and freedoms of others and of satisfying just demands based upon considerations of morality, religious values, security and public order in a democratic society." 
to prescribe a state of emergency or emergency situation, as stated in Article 12 of the Constitution of 1945, "the President states a state of emergency. The terms and conditions of the danger situation are set out in the Law."

The President's determination of a state of emergency is intended to determine further measures that would be able to overcome the situation, including restricting the human rights of citizens and other acts of exemption, in the framework of national salvation, such as exemptions from legislative powers, as stated in Article 22 paragraph 1 of the Constitution of 1945 "In an emergency compel, the President shall have the authority to establish government regulations in lieu of laws.”

According to Hosen,

"...the paradox begins with the vagueness of emergency powers stipulated in the Constitution and its failure to set out the criteria or the time-frame within which the powers may be exercised. This failure, in turn, facilitates the justification and use these powers. The only limitation is Parliament's ability to approve or disapprove the Perpu. Second paradox, the unstable nature of political alignments, the weakness of party structures, economic crisis, along with international pressures, all contribute to a pragmatic and politically oriented rule of law. Third, Indonesia's experience of the inability of Parliament and the courts (specialized administrative tribunals) to limit emergency powers is dissonant to the Gross-Dyzenhaus debate. And, the fourth the risks of using emergency powers and the premises of liberal constitutionalism." ${ }^{31}$

Given the current potential abusive policies, these points are relevant to demonstrate how these developments reflect the practice of exercising emergency powers during pandemic COVID-19, as well as updating the legal developments which have been newly introduced by the Indonesian government.

In Indonesia's legal system, emergency situations are subject to different concepts, norms, and prerequisites. Initially, the provisions of Law 6/1946, which were part of the staat van oorlog en beleg (SOB, Dutch) ${ }^{32}$, were rules made by the Dutch in Indonesia before independence. The law was repealed by Law 74/1957 which eventually changed to Law 23/1959 which is still in effect today. After the reforms were enacted, the Law 24/2007 and the Law 7/2012 provide norms related to danger conditions.

31 Nadirsyah Hosen, "Emergency powers and the rule of law in Indonesia" in V V Ramraj \& A K Thiruvengadam, eds, Emergency Powers in Asia: Exploring the Limits of Legality (UK: Cambridge University Press, 2010) 291.

32 Staat van Oorlog en Beleg (SOB) is a Dutch law which was applied in Indonesia when it was still controlled by the Dutch and was named the Dutch East Indies. SOB is fully referred to "Regeling op de Staat van Oorlog en van Beleg Stbl. 39-582. 


\section{Emergency Law in Indonesia}

Discussing the emergency situation in Indonesia (darurat), known as danger (bahaya) as normative term in Indonesia's legal system. Therefore, the use danger and emergency is interchangeable in this regards.

Nationally, a danger situation is regulated by four laws:

1. The Law 23/1959 on Determination of the State of Danger. Second, Law 24/2007 on Disaster Management; Third, Law 7/2012 on the Handling of Social Conflicts; Fourth, Law 6/2018 on Health Quarantine.

Article 1 Law 23/1959 defines the following 'state of danger' conditions:

"The President / Supreme Commander of the Armed Forces declares the whole or part of the territory of the Republic of Indonesia to be in jeopardy with the level of civilian emergency or military emergency or war situation, if, by rebellion, riot or natural disaster, so far as it is concerned that it cannot be solved by the usual equipments; 2 . arising from war or danger of war or concerned about the rape of the territory of the Republic of Indonesia in other ways; 3. State life is in jeopardy or under special circumstances it appears or it is feared that there are symptoms that could endanger the life of the State." 33

Law 23/1959 defines 'state of danger' as a condition that occurs in the event of a rebellion, riot, natural disaster, war, or war danger that endangers the life of the nation. In its elucidation it, mentions the five conditions categorised as the President's policy of dealing with the three levels of danger; civilian emergency, military emergency and state of war. The five conditions are: rebellion (armed conflict), riots, civil war, natural disasters and war.

2. Then, Law 24/2007 on Disaster Management, ${ }^{34}$ which also has different 'content' conditions, defines 'danger' as:

"Disasters are events or series of threatening events which threaten and suffer living and lives of people caused either by nature and/or by non-nature, or by human factors resulting in human casualties, environmental damage, property loss, and psychological affects.” 35

Law 24/2007 further divides disasters into three types: natural disasters, nonnatural disasters and social disasters. There are two types of disasters called natural disasters and social conflicts that fall into the social disaster section. In

33 In its elucidation of Article 1 of the Law 23/1959 states that: The statement of danger, made by the President in his responsibility and in this case the President is responsible for the People's Consultative Assembly. Evaluation of the events mentioned in paragraph 1 as a reason for the danger to be declared, submitted solely to the President; then the judge cannot test a statement of danger whether it is lawful or not. Vide: Elucidation of the 1945 Constitution before the amendment.

34 The word disaster refers to 'bencana', which cause an emergency situation or danger situation.

35 Article 1 paragraph 1 Law 24/2007 on Disaster Management 
relation to social disasters, the law defines them as "a disaster caused by events or series of events caused by humans involved in social conflicts among groups or civil society groups, and terror”. ${ }^{36}$

Law 24/2007 formulates a matter of declaration or statement relating to disasters, as described, a disaster in the partly territory or the whole territory of Indonesia, so then the applicable status includes: national disaster emergency status, provincial disaster emergency and district / city disaster emergency.

3. Regarding Social Conflict law, the Law 7/2012 also regulates part of a state of emergency that defines social conflict as follows:

"Social conflict is a feud and/or physical clash with violence between two or more community groups that takes place at a particular time and has a significant impact on social insecurity and disintegration that impairs national stability and impedes national development." ${ }^{37}$

The Law 7/2012 also regulates the status used in the event of social conflicts. In the event of social conflict occurring then the status used is the state status of the national conflict, the state status of the provincial conflict and the state status of the district/city conflict.

4. Law No. 6/2018 on Health Quarantine. The application of emergency in the law refers to the term of Kedaruratan Kesehatan Masyarakat, or Public Health Emergency (PHE). PHE means a community phenomenon characterized by the spread of infectious diseases and/or incidents caused by nuclear radiation, biological contamination, chemical contamination, bioterrorism, and food that pose a health hazard and potentially spread across region or cross-country" (article 1 number 2).

The PHE is formulated at Chapter IV, article 10-14 of the Law. As stated at article 11 ,

"In maintaining health quarantine in PHE, the Central Government quickly and accurately based on the importance of threats, effectiveness, support of resources, and operational techniques taking into account state sovereignty, security, economic, social, and cultural.”

In conclusion, these four laws generally govern the same type of danger but with different concepts. The Law 23/1959 mentions five conditions that are part of the status of civilian emergency, military emergency and state of war. Whereas Law 24/2007 uses national disaster emergency status, provincial disaster emergency status and municipal disaster emergency status. Law 7/2012 uses the state status of the national conflict, the state status of the provincial conflict and the state status of the district/city conflict. While Law 6/2018 uses the term PHE or Public Health Emergency. Compare to those laws, Law on 23/1959 is the oldest legal framework for emergency power in Indonesia, however it is less

36 Article 1 paragraph 4 Law 24/2007 on Disaster Management

37 Article 1 paragraph 1 Law 7/2012 on Social Conflict. In its elucidation also explained the physical clashes, including using weapons or not using weapons. 
adoptive of human rights, enacted prior to International Covenant on Civil and Political Rights (ICCPR).

The following table provides an easy comparison of the four laws in relation to the emergency status.

Comparison of Emergency Status and/or Dangerous Conditions

\begin{tabular}{|c|c|c|c|c|}
\hline Law & $\begin{array}{l}\text { Law } 23 / 1959 \text { on } \\
\text { Determination of the } \\
\text { State of Danger }\end{array}$ & $\begin{array}{l}\text { Law } 24 / 2007 \text { on Disaster } \\
\text { Management }\end{array}$ & $\begin{array}{l}\text { Law } 7 / 2012 \text { on } \\
\text { Social Conflict }\end{array}$ & $\begin{array}{l}\text { Law } 6 / 2018 \text { on } \\
\text { Health } \\
\text { Quarantine }\end{array}$ \\
\hline $\begin{array}{l}\text { Type of } \\
\text { conditions }\end{array}$ & $\begin{array}{l}\text { a. Rebellion (armed } \\
\text { conflict) } \\
\text { b. Riots } \\
\text { c. Civil war } \\
\text { d. Natural disasters } \\
\text { and } \\
\text { e. War. }\end{array}$ & $\begin{array}{l}\text { a. Natural disaster: } \\
\text { earthquakes, tsunamis, } \\
\text { volcanoes, floods, } \\
\text { droughts, hurricanes, } \\
\text { and landslides } \\
\text { b. Non-Natural Disasters: } \\
\text { technological failures, } \\
\text { modernization failures, } \\
\text { epidemics, and } \\
\text { epidemics; } \\
\text { c. Social Disasters: Social } \\
\text { Conflicts and Terror }\end{array}$ & Social conflicts & $\begin{array}{l}\text { Public health } \\
\text { emergency } \\
\text { situation }\end{array}$ \\
\hline Authority & President & $\begin{array}{l}\text { President, Governor, } \\
\text { District/City Mayor }\end{array}$ & $\begin{array}{l}\text { President, } \\
\text { Governor, } \\
\text { District/City } \\
\text { Mayor }\end{array}$ & $\begin{array}{l}\text { President, } \\
\text { Governor, } \\
\text { District/City } \\
\text { Mayor }\end{array}$ \\
\hline $\begin{array}{l}\text { Impleme } \\
\text { ntor }\end{array}$ & $\begin{array}{l}\text { Army, Police, } \\
\text { Prosecutor, } \\
\text { Governor, } \\
\text { District/City Mayor }\end{array}$ & $\begin{array}{l}\text { BNPB/National Disaster } \\
\text { Management Authority, } \\
\text { involves Search and } \\
\text { Rescue Agency, Army, } \\
\text { Police, Ministry of Health, } \\
\text { Ministry of Social PU, }\end{array}$ & Army, Police & $\begin{array}{l}\text { Central } \\
\text { Government } \\
\text { (Ministry of } \\
\text { Health), } \\
\text { Governor, } \\
\text { District/City } \\
\text { Mayor }\end{array}$ \\
\hline $\begin{array}{l}\text { Declaring } \\
\text { mechanis } \\
\mathrm{m}\end{array}$ & $\begin{array}{l}\text { Subjectivity of } \\
\text { President }\end{array}$ & $\begin{array}{l}\text { Consulting to } \\
\text { BNPB/National Disaster } \\
\text { Management Authority }\end{array}$ & $\begin{array}{l}\text { Legislative } \\
\text { consultancy }\end{array}$ & $\begin{array}{l}\text { Subjectivity of } \\
\text { President } \\
\text { (Ministry of } \\
\text { Health) }\end{array}$ \\
\hline Status & $\begin{array}{l}\text { - Civilian emergency } \\
\text { - Military emergency } \\
\text { and } \\
\text { - State of war. }\end{array}$ & $\begin{array}{l}\text { - National disaster } \\
\text { emergency status, } \\
\text { - Provincial disaster } \\
\text { emergency and } \\
\text { - District/city disaster } \\
\text { emergency. }\end{array}$ & $\begin{array}{l}\text { - The state status } \\
\text { of the national } \\
\text { conflict } \\
\text { - The state status } \\
\text { of the } \\
\text { provincial } \\
\text { conflict, and } \\
\text { - The state status } \\
\text { of the } \\
\text { district/city } \\
\text { conflict. }\end{array}$ & $\begin{array}{l}\text { Public health } \\
\text { emergency } \\
\text { - House } \\
\text { quarantine } \\
\text { - Territorial } \\
\text { quarantine } \\
\text { - Hospital } \\
\text { quarantine } \\
\text { - Large scale } \\
\text { social }\end{array}$ \\
\hline
\end{tabular}




\begin{tabular}{|l|l|l|l|l|}
\hline & & & & $\begin{array}{l}\text { restriction } \\
\text { (PSBB) }\end{array}$ \\
\hline Duration & $\begin{array}{l}6 \text { months, } \\
\text { extendable }\end{array}$ & No specific duration & $\begin{array}{l}90 \text { days, } \\
\text { extendable for 30 } \\
\text { days }\end{array}$ & $\begin{array}{l}\text { No specific } \\
\text { duration }\end{array}$ \\
\hline
\end{tabular}

The most relevant of these four laws, especially related to the legal handling of COVID-19 are the second and fourth, Law 24/2007 on Disaster Management and Law 6/2018 on Health Quarantine. This is because Article 1 of Law 3 of 24/2007 shows that non-natural disasters, include epidemics. Whilst Law 6/2018 deals with the health and conditions of the pandemic.

The question is, does the Indonesian government choose and affirm its status of emergency, and establish the principles of human rights pursued in the determination of its emergency status?

\section{Public Health Emergency to Non-Natural Disaster Emergency}

As its initial response, the Government of Indonesia issued Presidential Decree No. 11 of 2020 concerning Determination of Public Health Emergency (PHE). The decision was late due to their 'denial' stance but deserves to be appreciated as it is more appropriate for the policy efforts of the restrictions carried out, as stipulated in the Law on Health Quarantine. The emergency status as a legal basis must be an administrative decree/decision (KTUN/Keputusan Tata Usaha Negara, or beschikking in Dutch), not a regulation or legislation (regeling).

The problem is the Central Government has not planned to create Government Regulations (GR) on the Procedures for the Determination and Revocation of PHE, as mandated by article 10 paragraph (4) of Law 6/2020. In addition, the GR issued was limited to Large Scale Social Restriction (LSSR) status. The government does not want to declare a 'quarantine the territory' status. In fact, the scope of the LSSR only regulates school and workplace holidays, restrictions on religious activities and activities at the place or facility (Article 59 paragraph (3) of Law 6/2018).

The most distinguishing factor between the LSSR and the 'quarantine the territory' status is a matter for the government and their responsibility to uphold the basic needs of Indonesian citizens. As a result, government policies since late March 2020 have focused more on charity-based programs rather than on progressive strategic realisations to fulfil basic needs.

Whereas the Regulation in Lieu of Law 1/2020,38 another regulation which is enacted on the same day as the Presidential Decree and Government Regulation, is

38 Law 2/2020 on Stipulation of Regulation of Lieu of Law 1/2020 on State Financial Policy and Financial Stability for Handling Covid-19 Pandemic and/or in the context of Dealing with Threats that Harm National Economy and/or Financial System Stability. Vide: "Di Sidang MK, Sri Mulyani Sebut Perppu 1/2020 Telah Menjadi UU 2/2020", 
intended to save the health and the national economies. The Regulation in Lieu of Law 1/2020 focuses on the health budget spending, social safety nets and economic recovery of the business world and affected communities. The problem is that the affirmation of the protection of citizens' rights is not merely a matter of basic needs during an emergency, but also it is a guarantee of survival after COVID-19. What about the fate of workers who have been forced to take leave for dependents, be laid off, or outsourced workers who are vulnerable to socio-economic rights protection? While the provision of article 27 paragraph (2) of the Regulation in Lieu of Law $1 / 2020$ affirms the exclusion of legal liability for related officials.

How does this unclear legal policy on COVID-19 impact human rights protection efforts? Firstly, the president's political narrative through his spokesman concerning the 'civil emergency', ${ }^{39}$ is wrong and contrary to the obligation to fulfil the basic needs of the population. Besides this type of emergency focuses on a military or security approach, hence it is unrelated to health issues. The situation would be different if President Jokowi firmly issued a 'state of disaster' (Article 8 of Law 24/2007) and the determination of 'public health emergencies' with 'territorial quarantine' status (Article 55 paragraph 1 of Law No. 6/2018), where the state is bound by legal obligations to guarantee the availability of resources power for providing the basic necessities of life for citizens.

Second, the late and negligent anticipation of handling Covid-19, especially to the point of causing thousands of people to be exposed and hundreds of citizens and medical personnel deaths, is not just maladministration, but are forms of human rights violations, both civil and political rights as well as economic, social and cultural rights.

After 2 weeks, on April 13, 2020, the Government issued Presidential Decree No. 12 of 2020 concerning Determination of Non-Natural Disasters Distribution of Covid-19 as a National Disaster. This was a determination to emphasise the need to centralise policies, as the Presidential Decree affirmed, "Governors, regents and mayors as Chair of the Task Force for the Acceleration of Handling COVID-I9 in the regions, in setting policies in their respective regions, they must pay attention to the guidance policies of the Central Government”. From a legal standpoint, this shifts government policies that were initially based on the Law on Health Quarantine to change based on the Law on Disaster Management.

The problem is, on the ground is this creates overlapping policies because the coordination between the levels of government, both the Central Government and the Regional Government, and the Provincial Government and the City/Regency Governments, are not synchronous. Their lack of coordination has created tension,

https://nasional.kompas.com/read/2020/05/20/11415661/di-sidang-mk-sri-mulyani-sebutperppu-1-2020-telah-menjadi-uu-2-2020. (accessed 28 May 2020).

39 Kompas, "Jubir Presiden: Penerapan Darurat Sipil adalah Langkah Terakhir", Kompas (30 March 2020), online: <https://nasional.kompas.com/read/2020/03/ 30/15535741/jubirpresiden-penerapan-darurat-sipil-adalah-langkah-terakhir $>$. 
as happened between the Central Government and DKI Jakarta, ${ }^{40}$ or the Provincial Government of East Java and the City Government of Surabaya; ${ }^{41}$ recent examples of ongoing conflicts of authority. As a result, the handling of victims exposed to COVID-19 continues to grow, while referral hospital services can no longer accommodate COVID-19 patients.

The overlap and unsynchronized nature of the response have been exacerbated by the reality of the politicisation of policies ahead of regional elections in Indonesia. Not surprisingly, such a conflict has led to public distrust of the government as well as policies that were far from human rights law standards.

\section{THE USE OF EMERGENCY POWERS: A HUMAN RIGHTS PERSPECTIVE}

Indonesia has a number of strong human rights legal frameworks, housed within the constitution and through the ratification of a number of international human rights law provisions such as the International Covenant on Civil and Political Rights (ICCPR) and International Covenant on Economic Social and Cultural Rights (ICESCR). However, the government's policies especially in handling COVID-19, in does not reflect compliance with these human rights legal standards. Indeed, as stated by Lazar, a situation can be considered as urgent if it poses an instant threat which needs immediate intervention for the purpose of its elimination and mitigation. ${ }^{42}$

President Joko Widodo stated the social restriction policy to prevent the spread of the COVID-19 needed to be done on a larger scale, also accompanied by a 'civil emergency' policy. He stated,

"I ask for a large-scale social restrictions policy, physical distancing, be carried out more decisively, more disciplined and more effective. So, I have said before, that it needs to be accompanied by a civil emergency policy (via video conference from Bogor Palace, 30 March 2020." 43

Civil society and coalitions launched criticisms about 'civil emergencies', as they were considered to be potentially abused by the power holder for repression, and unrelated to the problem of the COVID-19 pandemic. The establishment of a 'civil

40 Kompas, "Blak-blakan Anies soal Data Covid-19 yang Tertutup | Sanksi Pelanggar PSBB Jakarta”, Kompas (14 May 2020), online: <https://megapolitan.kompas.com /read/2020/05/14/09085181/populer-jabodetabek-blak-blakan-anies-soal-data-covid-19-yangtertutup?page $=1>$.

41 CNN Indonesia, "Kisruh Risma vs Pemprov, PDIP Minta Khofifah Tidak Egois", (30 May 2020), online: CNN Indonesia <https:/www.cnnindonesia.com/nasional/20200530120327-32508204/kisruh-risma-vs-pemprov-pdip-minta-khofifah-tidak-egois>.

42 Nomi Claire Lazar, States of Emergency in Liberal Democracies (New York: Cambridge University Press, 2009).

43 Kompas, "Saat Jokowi Rencanakan Darurat Sipil Hadapi Pandemi Covid-19”, Kompas (31 March 2020), online: <https://nasional.kompas.com/read/2020/ 03/31/08201661/saat-jokowirencanakan-darurat-sipil-hadapi-pandemi-covid-1>. 
emergency' has the potential to increasingly jeopardise the security and health of citizens, because it enters into the area of restriction of civil liberties of expression. In practice, sociologically and historically, this status develops a repressive nature and nourishes the character of state authoritarianism. Indeed, serious violations of human rights often accompany emergency situations, which are variously known as "states of emergency," "states of exception," "states of siege," and "martial law." 44

Why is the 'civil emergency' not relevant? In addition to being substantively inappropriate for the handling of COVID-19, authorities who tasked with handling emergency powers are not related to health experts. This has been dominated by military officials, such as "First Minister, Minister of Security/Defense, Minister of Internal Affairs and Regional Autonomy; The Minister of Foreign Affairs, Chief of the Army, Chief of the Navy, Chief of the Air Force; and Head of State Police”.

Whilst from the perspective of human rights, the status of 'civil emergency' emphasises a repressive character. For example, it is possible to limit freedom of expression, association and assembly (Article 13 and 14 paragraph 1 of the Law 23/1959 on Determination of the State of Danger), confiscation of goods deemed to disturb security (Article 15 paragraph 1), press banning (article 17 paragraph 1), and police and body inspection (article 20).

After receiving strong criticism from the public, the government has ceased to mention the term 'civil emergency'. Unfortunately, there has been no formal apology, correction, or any further explanation as to why the government has changed the policy? What exactly are the legal consequences of these laws, both in terms of state administration and human rights? However, the National Police Chief, Gen. Idham Azis, also emphasised during a hearing at the House of Representatives Commission III (31 March 2020), that the police supported the government's plan to implement a 'civil emergency' in handling the COVID-19 outbreak. ${ }^{45}$

Meanwhile, the situation in the state of civil emergency has increasingly strengthened its practice in the field after Gen. Idham Azis issued the Decree of the Chief of Police Number: Mak/2/III/2020 concerning Compliance with Government Policy in Handling the Distribution of Covid-19.46 In addition, Gen. Idham Azis issued a telegram letter (ST/1100/IV/HUK.7.1./2020) signed by Criminal Department of Police, Gen. Commissaries Listyo Sigit Prabowo on behalf of the National Police Chief, on Saturday, April 4, 2020. The telegram letter regulates police obligations in dealing with the pandemic.

44 Special Rapporteur for States of Emergency, The Administration of Justice and the Human Rights of Detainees: Question of Human Rights and States of Emergency: Tenth Annual Report, hereinafter Special Rapporteur's Tenth Report, by Leandro Despouy, hereinafter Special Rapporteur's Tenth Report 11 20, 33, 48 (Comm'n on Human Rights, 1997).

45 Kompas, "Kapolri: Polri Dukung Darurat Sipil dalam Rangka Cegah Covid-19”, Kompas (31 March 2020), online: <https://nasional.kompas.com/read/2020/03/31/ 13552331/kapolri-polridukung-darurat-sipil-dalam-rangka-cegah-covid-19>.

46 Kompas, "Langkah Hukum di Tengah Penanganan Wabah Covid-19, Ini Pelanggaran yang Dibidik Polri”, Kompas (6 April 2020), online: <https://nasional.kompas .com/read/ 2020/04/06/10272001/langkah-hukum-di-tengah-penanganan-wabah-covid-19-ini-pelanggaranyang? page $=3>$. 
The letter regulates the operational rules for police in handling cases. However, it has the potential to cause an abuse of power, as point 5 , formulates carrying out cyber patrols to monitor the development of the situation and opinions aimed at spreading hoaxes related to COVID-19. It also relates to government policy in anticipating the spread of the outbreaks, insults to authorities or president and government officials. An insulting article is referred to in Article 207 of the Criminal Code, the humiliation could be punishable by a maximum imprisonment of 1 year and 6 months.

Another form of violation that is also regulated by the telegram letter is the resilience of internet data access during an emergency; the spread of COVID-19 related hoaxes and government policies in anticipation of the spread of the COVID19 outbreak as referred to in Article 14 or Article 15 of Law 1/1946 on Criminal Law Regulations. The criticism of government should be protected legally, a usual practice in democratic society without resorting to prosecuting it. Criticism is part of the freedom of expression, opinion, and academic freedom.

However, during the pandemic, there been increased pressure on civil liberties, such as threats to freedom of opinion, discussion, press freedom for journalists covering the news and scientists who had different opinions on the results of their research or studies. All are related to the government who justifies these unjust procedures due to the 'emergency'.

The laws being utilised in these cases are not always related directly to the laws which have been mentioned in the COVID-19 emergency law. Nevertheless, these cases have happened due to legitimate criticism against Indonesia's government policies in handling COVID-19 who have enabled numerous laws in order to silence it. In general, the emergency laws are pretexts for suppressing critics and other expressions against the government. This article will analyse ten cases to illustrate the pressure on freedom in Indonesia.

\section{Ilyani Case}

The FB post called hoax by Police's Criminal Department. This was posted on February 10, 2020. Ilyani wrote "There was a Chinese migrant worker who died in Meikarta, what illness? Australia calls Indonesia not yet having a detection reagent and WHO is worried that Indonesia has not been able to detect ...” Her posting is linked to the news link, "WHO Worried Coronavirus Has Not Been Detected in Indonesia”, CNN Indonesia, 10 February 2020.

Then, on March 20, 2020 at 22:00 five police investigators brought an arrest warrant, against Ilyani Sudardjat. The cell phone was detained, and she was interrogated for five hours until she made a written and filmed apology. Ilyani was released and was asked to report back every Monday. ${ }^{47}$

47 Kirana, Pengkerdilan Ruang Sipil di Tengah Pandemi (Jakarta: Lokataru, 2020). 


\section{Ravio Patra's Case}

Ravio Patra is an independent public policy researcher and member of the Westminster Foundation for Democracy, who often shares his personal views on Twitter. Ravio was secretly arrested by Metro Jaya Regional Police on Wednesday (22 April 2020) at 21:00 in Menteng, Central Jakarta, and was released on Friday (24 April 2020) at 08.30. The reason for this arrest was a broadcast message containing an invitation to riot and loot on 30 April, which was sent via Ravio's WhatsApp number by someone else. ${ }^{48}$

Other objections to this arrest were the inconsistencies of the investigator. Investigator stated Ravio was not arrested, but he was secured. They also accessed Ravio's work contract and personal financial records that were irrelevant to the case, even changing Ravio's email password. The most fatal factor, the article imposed on the victim was inconsistent, such as Article 28 paragraph 1 of the ITE Law on false news being Article 28 paragraph 2 of the ITE Law on hate speech based on racism/religion. ${ }^{49}$

Numerous civil society organisations, through the Coalition against Criminalisation and Manipulating Cases (KATROK) consider the process followed regarding the arrest and search of Ravio Patra was not conducted according to formal procedure. A member of the Coalition, and the Director of the Jakarta Legal Aid Institute, Arif Maulana, said that the police were unable to provide and show a warrant for arrest and search..$^{50}$ After 33 hours of interrogation, Ravio Patra was freed with witness status. The Jakarta Metropolitan Police is now being urged by the NGO coalition to seriously track down Ravio's mobile hacker.

\section{Three Student Activists' Case}

Three student activists in Malang, East Java, had been arrested for alleged vandalism with the intention of 'inciting the public'. This allegation was blurred, without clear evidence, and no legal basis prior to detention. This case is connected to the use of the police decree and the telegram letter relating to response of any criticism against officials.

The Head of Public Information Section (Kabagpenum) Police Public Relations Division, Asep Adi Saputra through live broadcasts on the Tribrata Youtube account of the Police Public Relations TV (22 April 2020), stated, "The vandalism case by three students in Malang who were alleged to have carried out acts of vandalism of property belonging to someone else or scribbled on walls with provocative words at

48 Vice, "Ciduk Ravio Patra, Polisi Ganti Tersudut Dugaan Intimidasi dan Alasan Absurd Penjemputan”, (24 April 2020), online: Vice <https://www.vice.com/id_id/article/ jgeway/peneliti-ravio-patra-bebas-setelah-diintimidasi-polisi-dan-ditangkap-polda-metro-tanpadasar-hukum-jelas>.

49 Ibid.

50 Tempo, "Kronologi Ravio Patra Diciduk Versi Polisi: Sempat Melawan”, Tempo (25 April 2020), online: <https://metro.tempo.co/read/1335600/kronologi-ravio-patra-diciduk-versi-polisisempat-melawan/full\&view $=\mathrm{ok}>$. 
six crime scene. ${ }^{{ }_{51}}$ Malang city police chief Comr. Leonardus Simarmata said they had confiscated several items of evidence, including two pieces of cardboard emblazoned with the words "Tegalrejo Melawan" (Tegalrejo Resists), motorbikes, three helmets, black spray paint and three cell phones from the suspects. ${ }^{52}$

Three students were said to provoke society against capitalists or groups of capital owners considered detrimental. The suspects were charged under Article 14 and Article 15 of Law 1/1946 on Criminal Law Regulations as well as Article 160 of the Criminal Code with the threat of a sentence of 10 years in prison. They were charged under Article 160 of the Criminal Code on public incitement, which carries a sentence of up to 10 years' imprisonment.

The students were activists who often took part in Kamisan protests, a weekly silent protest held every Thursday to demand state action in response human rights abuses, including in assisting Tegalrejo farmers in Malang to defend their land rights against corporations.

\section{Detik Journalist's Case}

An online media journalist Detik.com, received death threats from an unknown person. The threat was conveyed by unknown person via a WhatsApp message on 27 May 2020. The threat was related to the coverage of President Joko Widodo's visit to Summarecon Mall Bekasi, West Java, on Tuesday (26 May 2020). The Detik.com coverage related to these activities received intimidation until their identities were spread on social media or doxing after writing the news. ${ }^{53}$ Doxing is an attempt to search for and disseminate someone's personal information on the internet for the purpose of attacking and weakening someone or persecution online.

Doxing is a threat to press freedom. The methods employed to acquire this information include searching publicly available databases and social media websites, hacking and social engineering. Related to this death threat, Detik.com reported the case to the National Police Headquarters. Viva News reported that Detik.com had requested security from the Police of the journalist.

Doxing has happened on a number of occasions in Indonesia prior to the pandemic, especially attacking journalists. Journalism is not yet respected by state actors. Internally the journalists feel a sense of honour with their profession, because they are obedient to the principles of journalistic professionalism, the country still underestimates their contribution.

51 Kompas, "Dituding Lakukan Vandalisme, Tiga Mahasiswa di Malang Ditangkap”, Kompas (22 April 2020), online: <https:/nasional.kompas.com/read/2020/04/22/ 21292551/ditudinglakukan-vandalisme-tiga-mahasiswa-di-malang-ditangkap>.

52 The Jakarta Post, “Three East Java students arrested for 'inciting fight against capitalism”, The Jakarta Post (23 April 2020), online: <https://www.thejakartapost.com/ news/2020/04/23/threestudents-in-east-java-arrested-for-painting-anticapitalist-graffiti.html >.

53 DetikCom, "Wartawan Detik.com Jadi Korban Intimidasi dan Diancam Dibunuh", (27 May 2020), online: detik.com <https:/www.suara.com/wawancara/2019/11/13/ 102802/gilangparahita-kekerasan-terhadap-jurnalis-apa-negara-tidakdemokratis?utm_campaign=popupnews $>$. 


\section{Farid Gaban's Case}

Journalist Farid Gaban criticised Teten Masduki, the Minister of Cooperatives and Small and Medium Enterprises (SMEs) on twitter. His critique was related to government policies in prioritising support for corporations during the COVID-19 pandemic.

The Chairman of Cyber Indonesia, Muannas Alaidid, reported senior journalist Farid Gaban for allegedly spreading lies and deception, as well as insults to the authorities through social media. The report to the Jakarta Police was registered with Number: LP/3.001/V/YAN2.5/2020/SPKT PMJ dated May 27, 2020. Muannas said, "I do not question him (Farid) writing cooperatives, SMEs (small and medium enterprises) and solutions. Not that, he widened. But he tweeted about launching" (28 May 2020). ${ }^{54}$

Farid Gaban admitted that he was sued by Muannas and was threatened with a criminal case if he did not revoke his criticism of Teten. Muannas reported Farid to the Police under the cyber-defamation article 28 paragraph (2) of the ITE Law or Article 207 of the Criminal Code and/or Articles 14 and 15 of Law Number 1 of 1946.

Farid's criticism addressed the Minister of Cooperatives and SMEs policies during the epidemic and did not target Teten's person. According to him, criticism must be understood as the aspirations of the people.

\section{UGM Impeachment Discussion’ Case}

The President of the Constitutional Law Society (CLS), Aditya Halimawan, decided to cancel this discussion. Originally, the discussion program which was held online was conducted on Friday (29 May 2020) at 14.00 WIB. But was cancelled after his team received a threat if the scheduled discussion continued..$^{55}$ Initially this discussion was titled 'The Issue of President's Dismissal in the Middle of the Pandemic Viewed from the Constitutional Law System'. It was later changed to, 'Straightening the Issue of the Impeachment of the President Viewed from the Constitutional Law System'. ${ }^{56}$

The UGM Law Faculty Dean, Sigit Riyanto, in a written statement said the cancellation was due to speakers, moderators and liaison discussions agenda, as well as the chairman of CLS receiving terror and death threats the night before. "Starting from sending online motorcycle taxi reservations to the residence, text of death

54 Tirto, "Kasus Farid Gaban: Pemberangusan Kritik Warga Negara”, (30 May 2020), online: Tirto <https://tirto.id/kasus-farid-gaban-pemberangusan-kritik-warga-negara-fDED>.

55 Kompas, "Angkat Tema Pemberhentian Presiden, Panitia Diskusi CLS UGM Diancam hingga Acara Dibatalkan”, Kompas (30 May 2020), online: <https://regional.kompas.com/read/2020/ 05/30/12251181/angkat-tema-pemberhentian-presiden-panitia-diskusi-cls-ugm-diancamhingga>.

56 Kompas, "CLS UGM: Diskusi soal Pemberhentian Presiden Bersifat Akademis, Tak Terkait Politik”, Kompas (29 May 2020), online: <https://nasional.kompas.com/read/2020/05 /29/22541051/cls-ugm-diskusi-soal-pemberhentian-presiden-bersifat-akademis-tak-terkait>. 
threats, telephone calls, to the presence of several unknown people who came to their residence," said Sigit Riyanto to CNN Indonesia (30 May 2020). ${ }^{57}$

\section{Budi Setyarso's Case}

Budi Setyarso's Instagram account, as the Editor in Chief of Koran Tempo, was allegedly hacked. The hacking happened when he was guiding the Tempo discussion titled 'Why was the Discussion and Writing Terrorized?' on Sunday, May 31, 2020.

"Before the event ended, I saw an email notification pop up about activities on my Instagram account. Because the event was still running, I didn't open it immediately," Budi said via text message on Sunday, May 31, 2020. ${ }^{58}$ After the event was over, Budi checked his email, he found a message containing a report that there was unusual activity on his account, which was carried out using Chrome Mac OS X from Singapore.

Budi said, there were three sequential emails with a contiguous time. "First notifying a password change, which I did not do. The next two e-mails alerted me to unusual activity on my account," he said.

\section{Hacking the cell phone and other social media accounts}

A number of human rights activists and academics had experienced hacking of their WhatsApp accounts. This has happened to $\mathrm{Al}$ Araf, Director of Impartial Human Rights Monitor (May 23, 2020) and Usman Hamid, Director of Amnesty International Indonesia (June 5, 2020).

Others include law academics working on constitutional and human rights issues, including H.P. Wiratraman, Airlangga University (14 May 2020) and Riawan Tjandra, Atma Jaya University Yogyakarta (3 June 2020). The motive for hacking is unclear but the perpetrators use the network and WhatsApp for fraud. This happened on YLBHI (Indonesian Legal Aid Foundation)'s Instagram account which was hacked (15 June 2020), after his Institute discussed 'The Government's Authoritarianism Signs'. ${ }^{59}$ On the same day, an agrarian activist Roy Murtadho, was targeted as well. His Twitter and Instagram have been hacked after campaigning for social solidarity for Papuans. ${ }^{60}$

This is not new, as many activists and academics have been subject to hacking in an effort to fight the revision of the Corruption Eradication Commission Law and

57 CNN Indonesia, "Kronologi Teror dan Pembatalan Diskusi Mahasiswa Hukum UGM", (30) May 2020), online: $\boldsymbol{C N N}$ Indonesia <https:/www.cnnindonesia.com/nasional/202005301129 59-20-508203/kronologi-teror-dan-pembatalan-diskusi-mahasiswa-hukum-ugm>.

58 Tempo, “Akun Instagram Pemred Koran Tempo Diretas saat Memandu Diskusi”, Tempo (31 May 2020), online: <https://nasional.tempo.co/read/1348177/akun-instagram-pemred-korantempo-diretas-saat-memandu-diskusi/full\&view $=\mathrm{ok}>$.

59 Tempo, "Peretasan Akun Media Sosial Aktivis Tak Kunjung Surut", Koran Tempo (16 June 2020), online: <https://koran.tempo.co/read/nasional/454124/peretasan-akun-media-sosialaktivis-tak-kunjung-surut?>. 
reject the Omnibus Law. Law enforcement is ill-equipped to bring these cases to justice and no the data protection laws adopted. Privacy rights continue to be easily misused and attacked.

\section{Zoom Bombing Case}

The discussion on human rights and the problem of Papua fenced with \#PapuaLivesMatter, which was held by Amnesty International Indonesia, Friday (5 June 2020) afternoon, was terrorised. Disorders began to emerge when speakers from the Papua Human Rights Study and Advocacy Institute (Elsham Papua) Yuliana S Yabansabra spoke, about 30 minutes after the discussion began. During the discussion, the event was infiltrated by zoom-bombing. Their Zoom application was infiltrated by several anonymous accounts which interrupted the discussion with noise. Amnesty International Indonesia shall report its latest study to the United Nations (UN) under the title "Civil and Political Rights" Violations in Papua and West Papua.

The speaker was also terrorised via a telephone call from a stranger. ${ }^{61}$ Speakers such as Usman Hamid, Yuliana, and Tigor Hutapea (Pusaka Foundation) received telephone calls from numerous unknown subjects, state-coded numbers in America $(+1)$. They continued to be called until the discussion was interrupted.

Zoom bombing disturbance and terror are not novel; many previous webinar discussions have been also victims of zoom bombing, both held on campus, Administrative Court hearings in Papua and West Papua internet shutdown cases (3 June 2020) and research Institutes that discuss the curve problem of the COVID-19 epidemic in Indonesia

\section{Restriction against Researchers}

A number of research institutions have been pressured not to make reports that cause 'panic' amongst the people. One of the Jakarta-based Research Institutions, the Eijkman Institute for Molecular Biology, has asked researchers and staff not to use the institution's name in statements in the mass media. A number of researchers received a reprimand related to this, so that they no longer use agency affiliation. According to internal source at such research institute, the involvement of State Intelligence Agency (BIN) has driven such policy. ${ }^{62}$

These terror and intimidation tactics against civil societies, journalists, researchers and academics who have shown any criticism of the government's handling of the COVID-19 pandemic have been easily targeted.

61 SuaraCom, "Diskusi HAM Papua Lives Matter Diteror Zoombombing dan Telepon Nomor Asing”, (5 June 2020), online: SuaraCom <https://www.suara.com/news/2020 /06/05/144407/diskusi-ham-papua-lives-matter-diteror-zoombombing-dan-telepon-nomorasing>.

62 Anonymous, interview, 29 May 2020. 
10 Case Studies Threats to

Civil Liberties during the Pandemic Period

\begin{tabular}{|c|c|c|c|c|c|}
\hline $\mathrm{N}$. & Cases & Date & $\begin{array}{l}\text { Forms of Intimidation / } \\
\text { Attacks }\end{array}$ & Actors involved & $\begin{array}{l}\text { The Process of } \\
\text { Law Enforcement }\end{array}$ \\
\hline 1 & $\begin{array}{l}\text { Ilyani } \\
\text { Case }\end{array}$ & $\begin{array}{l}20 \text { March } \\
2020\end{array}$ & $\begin{array}{l}\text { Accused violating EIT } \\
\text { Law for disseminating } \\
\text { hoax, after criticism at } \\
\text { her FB }\end{array}$ & Police & $\begin{array}{l}\text { Cell phone was } \\
\text { confiscated, she } \\
\text { must report to the } \\
\text { police office every } \\
\text { Monday. }\end{array}$ \\
\hline 2 & $\begin{array}{l}\text { Ravio } \\
\text { Patra } \\
\text { Case }\end{array}$ & $\begin{array}{l}22 \text { April } \\
2020\end{array}$ & $\begin{array}{l}\text { Accused violating EIT } \\
\text { Law for disseminating } \\
\text { 'provocative statement', } \\
\text { after criticism to the } \\
\text { government through } \\
\text { numerous articles. }\end{array}$ & $\begin{array}{l}\text { Unknown } \\
\text { hacker, Police }\end{array}$ & $\begin{array}{l}\text { After } 33 \text { hours of } \\
\text { interrogation, } \\
\text { Ravio was freed } \\
\text { with a witness } \\
\text { status. The Jakarta } \\
\text { Metropolitan } \\
\text { Police is now being } \\
\text { urged by the NGO } \\
\text { coalition to } \\
\text { seriously track } \\
\text { down who is the } \\
\text { Ravio cell phone } \\
\text { hacker. }\end{array}$ \\
\hline 3 & $\begin{array}{l}\text { Three } \\
\text { Student } \\
\text { Activists' } \\
\text { Case }\end{array}$ & $\begin{array}{l}20 \text { April } \\
2020\end{array}$ & $\begin{array}{l}\text { MAA, SRA, and AFF } \\
\text { are said to want to } \\
\text { provoke society against } \\
\text { capitalists or groups of } \\
\text { capital owners, and } \\
\text { arrested for alleged } \\
\text { vandalism with the } \\
\text { intention of inciting the } \\
\text { public }\end{array}$ & Police & Suspected status \\
\hline 4 & $\begin{array}{l}\text { Detik } \\
\text { Journalist' } \\
\text { s Case }\end{array}$ & $\begin{array}{l}27 \text { May } \\
2020\end{array}$ & $\begin{array}{l}\text { Doxing, related to his } \\
\text { report on Jokowi's } \\
\text { activity }\end{array}$ & Unknown & $\begin{array}{l}\text { Reporting doxing } \\
\text { to Police, and } \\
\text { Police investigation }\end{array}$ \\
\hline 5 & $\begin{array}{l}\text { Farid } \\
\text { Gaban's } \\
\text { Case }\end{array}$ & $\begin{array}{l}27 \text { May } \\
2020\end{array}$ & $\begin{array}{l}\text { Reported for Cyber- } \\
\text { defamation and accused } \\
\text { violating EIT Law, } \\
\text { punishable for } 6 \text { years } \\
\text { imprisonment or } 1 \\
\text { billion rupiahs. }\end{array}$ & $\begin{array}{l}\text { Chairman of } \\
\text { Cyber } \\
\text { Indonesia, } \\
\text { Muannas } \\
\text { Alaidid }\end{array}$ & Police investigation \\
\hline 6 & $\begin{array}{l}\text { UGM } \\
\text { Impeach } \\
\text { ment } \\
\text { Discussio } \\
\text { n' Case }\end{array}$ & $\begin{array}{l}29 \text { May } \\
2020\end{array}$ & $\begin{array}{l}\text { Academic discussion } \\
\text { was cancelled, due to the } \\
\text { speaker, moderator and } \\
\text { liaison, as well as the } \\
\text { chairman of CLS } \\
\text { received terror and } \\
\text { death threats }\end{array}$ & $\begin{array}{l}\text { Unknown } \\
\text { hacker, terror }\end{array}$ & Police investigation \\
\hline
\end{tabular}




\begin{tabular}{|c|l|l|l|l|l|}
\hline N. & Cases & Date & $\begin{array}{l}\text { Forms of Intimidation / } \\
\text { Attacks }\end{array}$ & Actors involved & $\begin{array}{l}\text { The Process of } \\
\text { Law Enforcement }\end{array}$ \\
\hline 7 & $\begin{array}{l}\text { Budi } \\
\text { Setyarso's } \\
\text { Case }\end{array}$ & $\begin{array}{l}31 \text { May } \\
2020\end{array}$ & $\begin{array}{l}\text { Budi Setyarso's } \\
\text { Instagram account was } \\
\text { hacked. }\end{array}$ & $\begin{array}{l}\text { Unknown } \\
\text { hacker }\end{array}$ & $\begin{array}{l}\text { Reported to } \\
\text { Facebook }\end{array}$ \\
\hline 8 & $\begin{array}{l}\text { Hacking } \\
\text { the Cell } \\
\text { phones } \\
\text { and other } \\
\text { social } \\
\text { media } \\
\text { accounts }\end{array}$ & $\begin{array}{l}\text { 14, 23 } \\
\text { May } \\
\text { 2020, 3, } \\
\text { Jund } 15 \\
\text { June 2020 } \\
\text { twitter, Instagram, or } \\
\text { phone terror }\end{array}$ & $\begin{array}{l}\text { Hacking the WhatsApp, } \\
\text { hacker }\end{array}$ & Nonown report \\
\hline 9 & $\begin{array}{l}\text { Zoom } \\
\text { Bombing } \\
\text { Case }\end{array}$ & $\begin{array}{l}\text { 3 June } \\
\text { 2020 and } \\
\text { 5 June } \\
\text { 2020 }\end{array}$ & $\begin{array}{l}\text { Zoom Bombing at } \\
\text { webinar discussion and } \\
\text { court session }\end{array}$ & $\begin{array}{l}\text { Unknown } \\
\text { actors }\end{array}$ & No formal report \\
\hline 10 & $\begin{array}{l}\text { Restrictio } \\
\text { n Against } \\
\text { Researche } \\
\text { rs }\end{array}$ & $\begin{array}{l}\text { April, } \\
\text { May 2020 }\end{array}$ & $\begin{array}{l}\text { Obligation no longer } \\
\text { uses agency affiliation }\end{array}$ & Unreported & No formal report \\
\hline
\end{tabular}

These cases of threats to freedom of expression, opinion, academic freedom and freedom of the press reflect three things. Firstly, there is a silting in the quality of democracy in Indonesia and the rule of law. Moreover, in an emergency situation in the midst of the COVID-19 pandemic, there is a high number of cases of threats or intimidation against the fruition of civil liberties.

Secondly, even though the Indonesian government has not declared a state of 'civil emergency', the situation of terror and threats is mimicking Soeharto's military authoritarian regime. There have been inconsistent responses carried by national police after enacting rules (decree and telegram letter) which are detrimental to free expression. In an emergency, powers of local authorities and other sub-national agencies may be temporarily transferred to the central government to meet the requirement of a united response by the national authorities to protect life, property, public order and territorial integrity. ${ }^{63}$ However, the threats to civil liberties during the pandemic period above show draconian responses from the state's emergency powers.

Thirdly, the human rights standards and principles have been neglected and have been inconsistently applied. The requirements for 'permissible limitations' as well as adopting progressive interpretation, such as adopting legal doctrines of the Syracuse principles ${ }^{64}$ or General Comments as standards for interpretation have been

63 Elliot Bulmer, Emergency Powers: International IDEA Constitution-Building Primer 18 (International Institute for Democracy and Electoral Assistance (International IDEA), 2018).

64 UN Commission on Human Rights, the Siracusa Principles on the Limitation and Derogation Provisions in the International Covenant on Civil and Political Rights (1984). 
absent. Additionally, attacks on freedom of expression have not been processed by the law and enforcement mechanisms.

However, after the administrative court's decision on internet shutdown No. 230/G/TF/2019/PTUN-JKT on 3 June 2020; limits the arbitrariness of power in situations of danger or emergency. With this new development, Hosen's argument related to the inability of the courts (specialised administrative tribunals) to limit emergency powers is dissonant with the Gross-Dyzenhaus debate and needs to be updated. The state auxiliary bodies, such as the Ombudsman and the National Human Rights Commission, are also important in overseeing government policies and ensuring there is no abuse of power during the COVID-19 emergency period.

\section{CONCLUSION: NEW NORMAL, FLATTENING THE CURVE AND ABUSIVE POWER?}

As mentioned by Scott P. Sheeran, the international jurisprudence on states of emergency is inconsistent and divergent, and what now constitutes a public emergency is ubiquitous. ${ }^{65}$ This trend is underpinned by excessive judicial deference and abdication of the legal review of states' often dubious claims of a state of emergency. ${ }^{66}$ This confirms how the Indonesian government has applied the COVID-19 emergency powers.

The emergency power for handling the pandemic has been misused by providing immunity-locked regulation which reiterates legalized corruption, especially relating to those who have the authority in managing the pandemic. This enables government to enact policies without proper accountability in spending the state budget in the name of responding to the pandemic. On the other hand, the COVID-19 response has been dominated by military officials, rather than health and medical experts.

Although no civil emergency has been declared for exercising powers in the time of non-natural danger emergency, in practice the military approach prevails. The use of state repressive apparatuses remains dominant, including the involvement of State Intelligence Agency (Badan Intelejen Negara) in providing health care services.

The legitimate criticism, relating not only to the issue of democracy, rights and social justice, but threats such as criticising the increasing curve, the dangers of annulment of social distancing policies and predictions on 'herd immunity' in current health emergency situation are being penalised.

Lastly, the flattening of the curve for supporting the 'new normal' policy has been heavily influenced by economic reasons rather than public health ones. The policy does not meet the WHO's requirements. Therefore, unsurprisingly it showcases a repressive character in attempting to discipline civil society criticism. The COVID19 pandemic has provided ample evidence illustrating the government's mismanagement of this public health emergency.

65 Tempo, supra note 4 at 491-492.

66 Ibid. 
The situation has not changed much. The problem is data. Patient data, dissemination, referral hospital's capabilities, and also the readiness of medical personnel in dealing with the 'New Normal' policy. These are supported by the politics of the 'flattening curve'.

The implementation policy of handling COVID-19 has been dominated by the military, ${ }^{67}$ who are perceived as providing a convenient way of handling command. On the other hand, there is no effective control over the policy, budget and evaluation process. In the field there are overlaps and a distinct absence of the state in protecting and fulfilling the rights of citizens. This has served to consolidate oligarch networks and helping them to secure their vested interests in controlling political-economic resources rather than a 'spark' for wider reforms in the governance system.

In summary it is clear that human rights issues are facing serious risks. The COVID-19 emergency law violating many guarantees of legal protection and rule of law standards. It is apparent the issue of human rights has not yet become an effective strategy or approach in this non-natural disaster emergency situation. Not surprisingly, the 'New Normal' policy has created issues that are not only worrying from a medical perspective, but also from a broader human rights one. This signals the continuation of democracy decline, by the continued application of antidemocratic and restrictive policies. The only difference is this public health emergency is being used as the legal basis to restrict the rights of citizens across Indonesia.

\section{BIBLIOGRAPHY}

Agamben, Giorgio. State of Exception, translated by Kevin Attell (Chicago: University of Chicago Press, 2005).

Arif, Ahmad. "Ilmuwan dan Kekuasaan”, (13 May 2020), online: Kompas <https://kompas.id/baca/humaniora/ilmu-pengetahuan-teknologi/2020/05/13/ ilmuwan-dan-kekuasaan/>.

—. "Iqbal Elyazar: Jadikan Epidemiologi Memandu Indonesia”, (20 May 2020), online: Kompas <https://kompas.id/baca/humaniora/ilmu-pengetahuan-tek nologi/2020/05/20/iqbal-elyazar-jadikan-epidemiologi-memandu-indonesia/>.

Barendt, Eric. An Introduction to Constitutional Law, Clarendon Law Series (Oxford: Oxford University Press, 1998).

BioTechniques. "Dangers of False Negative COVID-19 PCR Tests", (29 May 2020), online: <https://www.biotechniques.com/coronavirus-news/false-negatives-howaccurate-are-pcr-tests-for-covid-19/>.

67 Evan A Laksmana \& Rage Taufika, "How 'militarized' is Indonesia's COVID-19 management?”, (27 May 2020), online: The Jakarta Post <https://www.thejakartapost.com/ academia/2020/05/27/how-militarized-is-indonesias-covid-19-management.html . 
Bozinovic, Filip. "Finding the Limits of France's State of Emergency" (2017) 2017:4 Claremont-UC Undergraduate Research Conference on the European Union 13-31.

Bulmer, Elliot. Emergency Powers: International IDEA Constitution-Building Primer 18 (International Institute for Democracy and Electoral Assistance (International IDEA), 2018).

Chen, Albert H Y. "Emergency powers, constitutionalism and legal transplants: the East Asian experience” in Arun K Thiruvengadam \& Victor V Ramraj, eds, Emergency Powers in Asia: Exploring the Limits of Legality (Cambridge University Press, 2009) 57.

Chowdhury, Subrata Roy. Rule of Law in a State of Emergency: The Paris Minimum Standards of Human Rights Norms in a State of Emergency (London: Printer Publisher, 1989).

CNN Indonesia. "Kisruh Risma vs Pemprov, PDIP Minta Khofifah Tidak Egois", (30 May 2020), online: CNN Indonesia <https://www.cnnindonesia.com/ nasional/20200530120327-32-508204/kisruh-risma-vs-pemprov-pdip-mintakhofifah-tidak-egois>.

. "Kronologi Teror dan Pembatalan Diskusi Mahasiswa Hukum UGM", (30 May 2020), online: CNN Indonesia <https://www.cnnindonesia.com/nasional/ 20200530112959-20-508203/kronologi-teror-dan-pembatalan-diskusimahasiswa-hukum-ugm>.

Despouy, Leandro. Special Rapporteur for States of Emergency, The Administration of Justice and the Human Rights of Detainees: Question of Human Rights and States of Emergency: Tenth Annual Report, hereinafter Special Rapporteur's Tenth Report, by Leandro Despouy, hereinafter Special Rapporteur's Tenth Report 11 20, 33, 48 (Comm'n on Human Rights, 1997).

DetikCom. "Wartawan Detik.com Jadi Korban Intimidasi dan Diancam Dibunuh", (27 May 2020), online: detik.com <https:/www.suara.com/wawancara/2019/ 11/13/102802/gilang-parahitakekerasan-terhadap-jurnalis-apa-negara-tidakdemokratis?utm_campaign=popupnews $>$.

Dyna, Rochmyaningsih. "Open the doors for us.' Indonesian scientists say government snubs offers to help fight coronavirus" Science Magazine (18 April 2020), online: <https://www.sciencemag.org/news/2020/04/open-doors-us-indo nesian-scientists-say-government-snubs-offers-help-fight-coronavirus〉.

Hosen, Nadirsyah. "Emergency powers and the rule of law in Indonesia" in V V Ramraj \& A K Thiruvengadam, eds, Emergency Powers in Asia: Exploring the Limits of Legality (UK: Cambridge University Press, 2010) 291.

Hunter, Nan D. The Law of Emergencies: Public Health and Disaster Management (Burlington: Butterworth-Heinemann, 2009).

Khakee, Anna. Securing democracy : a comparative analysis of emergency powers in Europe, policy paper no 30 ed (Geneva Centre for the Democratic Control of Armed Forces (DCAF), 2009). 
Kirana. Pengkerdilan Ruang Sipil di Tengah Pandemi (Jakarta: Lokataru, 2020).

Kompas. "Angkat Tema Pemberhentian Presiden, Panitia Diskusi CLS UGM Diancam hingga Acara Dibatalkan”, Kompas (30 May 2020), online: <https://regional.kompas.com/read/2020/05/30/12251181/angkat-temapemberhentian-presiden-panitia-diskusi-cls-ugm-diancam-hingga $>$

—. "Blak-blakan Anies soal Data Covid-19 yang Tertutup | Sanksi Pelanggar PSBB Jakarta”, Kompas (14 May 2020), online: <https://megapolitan. kompas.com/read/2020/05/14/09085181/populer-jabodetabek-blak-blakananies-soal-data-covid-19-yang-tertutup?page $=1>$.

. "CLS UGM: Diskusi soal Pemberhentian Presiden Bersifat Akademis, Tak Terkait Politik”, Kompas (29 May 2020), online: <https://nasional.kompas. com/read/2020/05/29/22541051/cls-ugm-diskusi-soal-pemberhentian-presidenbersifat-akademis-tak-terkait>.

"Dituding Lakukan Vandalisme, Tiga Mahasiswa di Malang Ditangkap", Kompas (22 April 2020), online: <https://nasional.kompas.com/read/2020/04/ 22/21292551/dituding-lakukan-vandalisme-tiga-mahasiswa-di-malangditangkap>.

—. "Jokowi Akui Pemerintah Rahasiakan Sejumlah Informasi soal Corona", Kompas (13 March 2020), online: <https://nasional.kompas.com/read/2020/03/ 13/16163481/jokowi-akui-pemerintah-rahasiakan-sejumlah-informasi-soalcorona>.

—_. "Jubir Presiden: Penerapan Darurat Sipil adalah Langkah Terakhir", Kompas (30 March 2020), online: <https://nasional.kompas.com/read/2020/03/30/155 35741/jubir-presiden-penerapan-darurat-sipil-adalah-langkah-terakhir> .

—. "Kapolri: Polri Dukung Darurat Sipil dalam Rangka Cegah Covid-19", Kompas (31 March 2020), online: <https://nasional.kompas.com/read/2020 /03/31/13552331/kapolri-polri-dukung-darurat-sipil-dalam-rangka-cegah-covid$19>$.

—. "Langkah Hukum di Tengah Penanganan Wabah Covid-19, Ini Pelanggaran yang Dibidik Polri", Kompas (6 April 2020), online: <https://nasional.kompas .com/read/2020/04/06/10272001/langkah-hukum-di-tengah-penanganan-wabah -covid-19-ini-pelanggaran-yang?page $=3>$.

—. "LP3ES Catat Ada 37 Pernyataan Blunder Pemerintah soal Covid-19", Kompas (6 April 2020), online: <https://nasional.kompas.com/read/2020/04/ 06/17522121/lp3es-catat-ada-37-pernyataan-blunder-pemerintah-soal-covid$19>$.

—. "Saat Jokowi Rencanakan Darurat Sipil Hadapi Pandemi Covid-19”, Kompas (31 March 2020), online: <https://nasional.kompas.com/read/2020/03/31/ 08201661/saat-jokowi-rencanakan-darurat-sipil-hadapi-pandemi-covid-1>.

Kumparan. "Peneliti UI soal Corona Masuk RI Sejak Januari: Pemerintah Sudah Tahu”, (20 April 2020), online: Kumparan <https://kumparan.com/ kumparan 
sains/peneliti-ui-soal-corona-masuk-ri-sejak-januari-pemerintah-sudah-tahu$1 \mathrm{tG} 7 \mathrm{saj} 5 \mathrm{ob}>$.

—_. "Rasio Tes PCR Corona di Indonesia Terendah Ketiga di Asia Tenggara", (7May 2020), online: <https://kumparan.com/kumparannews/rasio-tes-pcrcorona-di-indonesia-terendah-ketiga-di-asia-tenggara-1tMesGDnTUh>.

Laksmana, Evan A \& Rage Taufika. "How 'militarized' is Indonesia's COVID-19 management?" (27 May 2020), online: The Jakarta Post <https://www. thejakartapost.com/academia/2020/05/27/how-militarized-is-indonesias-covid19-management.html>.

Lazar, Nomi Claire. States of Emergency in Liberal Democracies (New York: Cambridge University Press, 2009).

Power, Thomas P. "Jokowi's Authoritarian Turn and Indonesia's Democratic Decline” (2018) 54:3 Bulletin of Indonesian Economic Studies 307-338.

Sheeran, Scott. "Reconceptualizing States of Emergency under International Human Rights Law: Theory, Legal Doctrine, and Politics” (2013) 34:3 Michigan Journal of International Law (Legal Doctrine, and Politics) 491.

SuaraCom. "Diskusi HAM Papua Lives Matter Diteror Zoombombing dan Telepon Nomor Asing", (5 June 2020), online: SuaraCom <https://www.suara.com /news/2020/06/05/144407/diskusi-ham-papua-lives-matter-diteror-zoombomb ing-dan-telepon-nomor-asing>.

Tempo. "Akun Instagram Pemred Koran Tempo Diretas saat Memandu Diskusi”, Tempo (31 May 2020), online: <https://nasional.tempo.co/read/1348177/akuninstagram-pemred-koran-tempo-diretas-saat-memandu-diskusi/full\&view=ok> .

—. "Ilmuwan Indonesia Merasa Tidak Dilibatkan Dalam Menangani Virus Corona (ABC Australia)", TempoCo (18 May 2020), online: <https:/www.tempo.co/abc/5597/ilmuwan-indonesia-merasa-tidak-dilibatkandalam-menangani-virus-corona>.

—. "Kronologi Ravio Patra Diciduk Versi Polisi: Sempat Melawan", Tempo (25 April 2020), online: <https://metro.tempo.co/read/1335600/kronologi-raviopatra-diciduk-versi-polisi-sempat-melawan/full\&view $=\mathrm{ok}>$.

—_. "Peretasan Akun Media Sosial Aktivis Tak Kunjung Surut", Koran Tempo (16 June 2020), online: <https://koran.tempo.co/read/nasional/454124/peretasanakun-media-sosial-aktivis-tak-kunjung-surut?>.

"Pernyataan Lengkap Jokowi Soal New Normal Damai dengan Covid-19", Tempo (16 May 2020), online: <https://nasional.tempo.co/read/1342885/ pernyataan-lengkap-jokowi-soal-new-normal-damai-dengan-covid-19>.

The Jakarta Post. "Three East Java students arrested for 'inciting fight against capitalism”", The Jakarta Post (23 April 2020), online: <https://www. thejakartapost.com/news/2020/04/23/three-students-in-east-java-arrested-forpainting-anticapitalist-graffiti.html>. 
Time. "World Health Organization Declares COVID-19 a 'Pandemic.' Here's What That Means" Time (11 March 2020), online: <https://time.com/ 5791661/who-coronavirus-pandemic-declaration/>.

Tirto. "Gugus Tugas COVID-19: 55 Tenaga Medis Meninggal Saat Pandemi Corona”, (6 May 2020), online: Tirto <https://irto.id/flvF>.

—_. "Kasus Farid Gaban: Pemberangusan Kritik Warga Negara”, (30 May 2020), online: Tirto <https://irto.id/kasus-farid-gaban-pemberangusan-kritik-warganegara-fDED>.

UN Commission on Human Rights. The Siracusa Principles on the Limitation and Derogation Provisions in the International Covenant on Civil and Political Rights (1984).

Vice. "Ciduk Ravio Patra, Polisi Ganti Tersudut Dugaan Intimidasi dan Alasan Absurd Penjemputan”, (24 April 2020), online: Vice <https://www.vice. com/id_id/article/jgeway/peneliti-ravio-patra-bebas-setelah-diintimidasi-polisidan-ditangkap-polda-metro-tanpa-dasar-hukum-jelas>.

\section{Laws}

Indonesian Constitution, 1945 and its amendment

Law 23/1959 on Determination of the State of Danger.

Law 24/2007 on Disaster Management;

Law 14 /2008 concerning Public Information Openness.

Law 7/2012 on the Handling of Social Conflicts;

Law 6/2018 on Health Quarantine.

Law 2/2020 on Stipulation of Regulation of Lieu of Law 1/2020 on State Financial Policy and Financial Stability for Handling Covid-19 Pandemic and/or in the context of Dealing with Threats that Harm National Economy and/or Financial System Stability.

Presidential Decree 12/2020 on the change of Task Force for the Acceleration Handling of Corona Virus Disease 2109 (Covid-19), 20 March 2020

Herlambang P. Wiratraman is a senior lecturer and researcher at the Constitutional Law Department as well as at the Center of Human Rights Law Studies (HRLS), Faculty of Law Universitas Airlangga. His current research is on the role of judiciaries, state institutions for democracies, press freedom and academic freedom. Herlambang earned his MA degree at Office of Human Rights and Social Development, Graduate Faculty Mahidol University in 2006, and in 2014 his PhD (dr) at at the Van Vollenhoven Institute of Leiden Law School, with the dissertation "Press Freedom, Law and Politics in Indonesia: A Socio Legal Study". Currently, Coordinator of Indonesian Caucus for Academic Freedom (KIKA, 2019-present), 
and an expert team member on SLEEI Project (Strengthening Legal Education for Eastern Indonesia, part of Orange Knowledge Fund NUFFIC-Neso). 